\title{
Analysis of the Relationship of Maturity and Quality Management in Projects
}

\author{
Fernanda Malagutti ${ }^{1}$, Rosley Anholon ${ }^{1}$, Olívio Novaski ${ }^{1} \&$ Jefferson de Souza Pinto $^{1}$ \\ ${ }^{1}$ School of Mechanical Engineering, State University of Campinas, Campinas, Brazil \\ Correspondence: Rosley Anholon, School of Mechanical Engineering, University of Campinas, Campinas, Brazil. \\ Tel: 55-19-3521-3312. E-mail: rosley@fem.unicamp.br
}

Received: September 17, 2014

Accepted: October 10, 2014

Online Published: October 13, 2014

doi:10.5430/bmr.v4n1p1

URL: http://dx.doi.org/10.5430/bmr.v4n1p1

\begin{abstract}
Currently, the project management in enterprises has become a predominant factor. Often, companies execute their strategies through projects, and thus adopting tools and methodologies that improve the performance, enhancing competitive advantages. This study aims to examine the relationship of maturity and quality project management. For this, a survey was conducted in 10 companies in different segments, using two questionnaires: one, on project management aspects; another, about project maturity model (P3M3). The results of the studies have shown that companies that use quality tools in managing their projects have higher maturity levels.
\end{abstract}

Keywords: Project management, Project quality management, Quality control tools

\section{Introduction}

Faced with rapid changes, due to intense globalization, companies are constantly seeking new technologies and tools that support their competitiveness in the market today (Zhang \& London, 2013). There are numerous strategies that companies routinely perform in order to achieve their goals. These strategies are often driven by projects managed through methodologies and management tools that guide their development.

The number of projects that companies run simultaneously, in parallel with the demands that surround them, implies a focus on management to avoid possible risks, for example, not reaching their targets, not meeting deadlines and exceeding planned costs, divert the scope proposed, among others. Therefore, companies seek to implement projects based on consistent methodologies and tools in order to ensure success and develop management maturity in an organizational context (Aubry, 2010).

According to Ellis and Berry (2013), maturity in Project management is the implementation of a standard methodology and accompanying processes such that there exists a high likelihood of repeated successes. The concept of maturity in projects is becoming more popular in organizations since it allows evaluating the practices carried out to identify the points that can be improved and develop continuing actions for giving effectiveness to the performance in project management. Studies indicate a variety of maturity models in projects that can be used by organizations. There are also several studies that point to factors that contribute to raising the maturity in project management, although few studies reported the relationship of maturity in project management and quality management in projects (Moraes \& Laurindo, 2013).

In this context, the purpose of this study is to analyze the relationship of maturity in project management and quality management in projects, assuming that companies using quality tools in project management are in greater levels of maturity. Thus, the key question that guides the research is if companies that use quality tools in project management have higher levels of maturity. The initial hypothesis is that there is positive correlation between quality tools use and maturity in project, but this will be proved throughout the research.

\section{Literature Review}

\subsection{Project Management, Maturity and Quality Management}

According to Ojiako, Ashleigh, Chipulu and Maguire (2011), project is a temporary endeavor undertaken to create a product, a service or a unique result. The concept of design in companies is very significant, since it is used to enable strategies developed by the organization to achieve the objectives and goals. For the same authors, a project can be 
considered any series of activities and tasks that have a specific objective to be completed within certain specifications. Besides, have defined start and end dates, funding limits (if applicable), consume human and nonhuman resources (i.e., money, people, equipment) and they are multifunctional (i.e., cut across several functional lines).

The carrying out of projects in an organized manner as planned is called project management. According to Kerzner (2009) project management is the planning, organizing, directing, and controlling of company resources for a relatively short-term objective that has been established to complete specific goals and objectives. To Garel (2012), the basis of project management theory includes, as is the case of many management theories an articulated collection of best practices drawn for the most part from the study of major North American engineering projects

Focusing on the maturity of projects, the concept of maturity was established in organizations for conducting projects in order to achieve the goals set in planning. That is, the "mature" state means that the organization has reached maximum development (Andersen \& Jessen, 2003).

To achieve this level of maturity it requires that companies adopt methodologies, tools and deploy processes in order to establish the continuous improvement of the project implementation process, thus achieving higher levels of maturity (PMBOK, 2013).

According to Passian, Sankaran and Boyodell (2012), maturity in project management is the implementation of a standard methodology and accompanying processes such that there exists a high likelihood of repeated successes. Bolles and Hubbard (2007) describe that the more uniformly and consistently a mature project business management process is applied, the greater the obtained results and benefits will be.

Finally, it is important to present some concepts related to quality management in projects. According to the PMBOK (2013), quality management in projects includes the processes and activities of the performing organization that determine quality policies, objectives and responsibilities, so that the project meets the needs for which it was undertaken. It implements the quality management system through policies and procedures by continuous improvement activities of processes performed throughout the project as appropriate.

Flybjerg (2013) and Yingsheng Du and Youchun Tang (2013) defines quality in projects as meeting customer requirements, i.e., meeting the technical demands and guaranteeing the results. Quality management encompasses management and product design, and applies to all projects, regardless of the nature of the product. Kumar and Mangalam (2010) and Caulliraux et al (2012) adds that Project quality management is a result of hard, deliberate work that begins with planning, includes consideration of contributing elements, applies disciplined process and tools, and never, ever ends.

Lastly, it is important mention that quality management complements project management, and the two disciplines recognize and seek the importance of customer satisfaction, prevention rather than inspection, continuous improvement and accountability of management (Kerzner, 2009).

\section{Methodology}

In order to conduct the survey were selected 10 companies from various segments located in different regions of Brazil. For each company were sent two questionnaires, one on general aspects of project management and another questionnaire on level of maturity in projects according the P3M3 model (PMBOK, 2013).

For this study, the procedures for data collection were divided into four sequential phases. Initially, questionnaires were developed (phase 1), and subjected to two companies for testing (phase 2), the test was performed after a correction of questionnaires (phase 3) and finally applied to all companies (phase 4), and later the results were analyzed as presented in Figure 1.

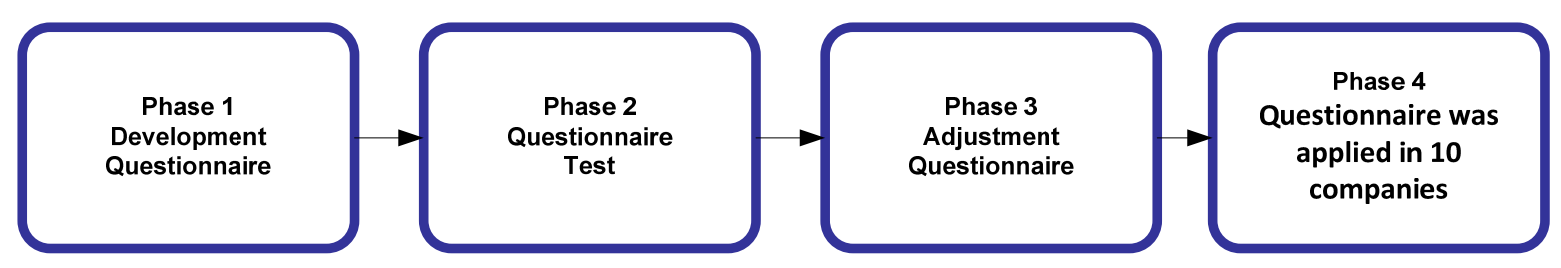

Figure 1. Procedure for the development of an instrument for collecting research data

Source: prepared by authors 


\subsection{Development of a questionnaire}

The first questionnaire was about maturity in project management. To identify the maturity level of companies it was used the model P3M3. The authors of this paper chose this model for the following reasons:

- the model classifies the company level, since the methodology ranks companies in low and high maturity for secondary analysis;

- identification can be made by the project manager;

- the model P3M3 is easy to interpret and can be rapidly examined; and

- it is a free model, which facilitated the use of all businesses.

The model P3M3 consists of nine questions, the first question concerns the general aspects of the organization. The purpose of this question is to know which of the five maturity levels best describes the organization's position in the projects executed. The two from eight questions relate to the perspectives control management, benefits management, financial management, engagement of stakeholders, risk management, organizational management and resource management. To finish, the last question describes the general aspects of the organization with a focus on project management.

The questionnaire 2 presents questions on aspects of project management in four separate interfering factors people, processes, miscellaneous tools and technologies, and tools for quality control. The aspect of quality tools can be considered as an integral factor of technologies and tools, nevertheless, in the present study it is aimed to assess the quality tools used in projects specifically analyzing what tools are most studied and used in companies, which are considered most important for them. Thus, the questionnaire consisted of the following structure, shown in table 1:

Table 1. Factor, description and questions addressed in the questionnaire on aspects of project management. Source: prepared by authors

\begin{tabular}{|c|c|c|}
\hline Factor & Description & $\begin{array}{l}\text { Number of } \\
\text { questions }\end{array}$ \\
\hline $\begin{array}{l}\text { Tools for quality } \\
\text { control }\end{array}$ & Analysis of the seven quality control tools. & 7 \\
\hline $\begin{array}{l}\text { Technologies and } \\
\text { miscellaneous } \\
\text { tools }\end{array}$ & $\begin{array}{l}\text { Technologies and miscellaneous that assist in the planning and } \\
\text { execution of projects in companies }\end{array}$ & 11 \\
\hline Processes & $\begin{array}{l}\text { The "process" factor establishes actions and established guidelines, } \\
\text { which are used in various projects carried out in companies }\end{array}$ & 8 \\
\hline People & $\begin{array}{c}\text { The "people" factor deals with those involved in projects in general, } \\
\text { addressing knowledge of standards, knowledge of skills and } \\
\text { knowledge of the establishment and responsibility matrix }\end{array}$ & 3 \\
\hline
\end{tabular}

In order to analyze the results of the questionnaire on aspects of project management a score methodology was developed, according to the knowledge and frequency of adoption of issues addressed. The level of importance of each aspect was scored by the respondent according to their perception of the company where they work. Table 2 presents a model example of a questionnaire applied to the scores set out in the field samples, as Table 3 presents the score established for each level displayed. See the complete questionnaire in appendix.

Table 2. Header of the questionnaire presented to the companies studied. Source: prepared by authors

\begin{tabular}{l|l|l|l|l|l|l|l|l|l|l|l}
\hline & Unknown & Never & Rarely & Sometimes & Often & \multicolumn{3}{|c|}{ Always } & \multicolumn{3}{|c}{ Level of importance } \\
\hline & & & & & & & 0 & 3 & 5 & 7 & 10 \\
\hline \multirow{2}{*}{ Question } & & & & & & & & & & & \\
& & & & & & & & & & & \\
\hline
\end{tabular}


Table 3. Scores assigned to each level presented. Source: prepared by authors

\begin{tabular}{c|c|c|c}
\hline Frequency & Score & Importance & Score \\
\hline Unknown & 0.00 & Importance 0 & 0.00 \\
\hline Never & 0.00 & Importance 3 & 3.00 \\
\hline Rarely & 0.25 & Importance 5 & 5.00 \\
\hline Sometimes & 0.50 & Importance 7 & 7.00 \\
\hline Often & 0.75 & Importance 10 & 10.00 \\
\hline Always & 1.00 & & \\
\hline
\end{tabular}

In order to carry out the score of each aspect addressed by the questionnaire it was drawn up one expression (equation 1) to note of frequency and other to note of importance.

$$
\text { Note of frequency }=(\mathrm{UxO} 0)+(\mathrm{NxO})+(\mathrm{Rx} 0.25)+(\mathrm{Sx} 0.5)+(\mathrm{Ox} 0.75)+(\mathrm{Ax} 1.0)
$$

Where $\mathrm{U}$ is total answers attributed to unknown, $\mathrm{N}$ is total answers attributed to never, $\mathrm{R}$ is total answers attributed to rarely, $\mathrm{S}$ is total answers attributed to sometimes, $\mathrm{O}$ is total answers attributed to often and, finally, A total answers attributed to always. To analyze the importance we elaborated the expression bellow (equation 2).

Note of importance $=(I 0 x 0)+(I 3 x 0.25)+(I 5 x 0.5)+(I 7 x 0.75)+(I 10 \times 1.0)$

Where I0 is the total of the answers attributed to importance $0, \mathrm{I} 3$ is the total of the answers attributed to importance 3 , I5 is total answers attributed to the importance 5, I7 is the total of the answers attributed to importance 7 and I10 is the total of the answers attributed to importance 10.

\section{Results}

\subsection{Analysis and discussion of results: companies with high and low maturity}

This topic start with the analysis of the aspects of maturity of the companies studied on the model P3M3. This model classifies companies into five levels of maturity. In this study, whose field sample was composed of 10 companies, 3 $(30 \%)$ of these companies were in level 1 (process knowledge) of maturity, the perceived level of maturity 2 (repetition of the process) is observed in $2(20 \%)$ companies, whereas, level 3 of maturity (process definition) is found in $3(30 \%)$ companies, the perceived level 4 (managed process) was observed in $2(20 \%)$ companies. No company studied reached the maturity level 5 (optimized process).

For purposes of comparative analyses, companies were classified into two categories, namely: high maturity and low maturity. The high-ranked companies are those that have reached maturity level 3,4 and 5, whereas the companies that were classified as low level of maturity reached levels 1 and 2. In this study, five companies (50\%) were classified at a high level of maturity and $5(50 \%)$ with low level of maturity in projects. The analysis of the projects characteristics was done to companies classified as low and high level of maturity.

\subsubsection{Companies with low level of maturity}

Let's start with companies with as low level of maturity, in the case of general aspects of the organization, most companies report that design processes are not documented nor described, consequently, there is no established design processes.

The project execution is successful due to responsibilities of certain employees, obtaining, thus, variation in the performance of various projects undertaken. Projects are carried frequently out within their budget and above planned levels, and the processes are poorly developed or not established. There is no supporting documentation, nor standardized terminology knowledge of everyone involved in the projects. Only one of the companies in this group reported that the project management practices were established, with some people within the organization with proper guidance, trained to carry out the projects, re-apply project management practices and repeat the positive results.

The initiatives are implemented in accordance with the project plan, but the organization still has inadequate measures of success as ambiguities, inconsistencies in terms of business objectives, deficiencies in risk management, as well as weaknesses in change management and communication.

Only one company with low level of maturity reported, regarding the issue that addresses general aspects of the organization, that management and process techniques are documented, standardized and integrated with business 
processes. Also being possible training and capacitating of people to implement the projects within the organization. In the specific case, it is a company in the field of electricity and gas, and for the approval and implementation of projects in the organization, it needs to process detailed description of procedures and documentation of projects.

It was observed that there is an analysis of the quality of the products arising as a comparative project, aiming to improve design processes and eliminate any deficiencies. As for control management, most companies with a low level of maturity report that the concept of project management has been gradually absorbed by the organization, specifically the most involved in projects, such as project managers.

A company in this group showed that the terminology of project management is used by only some members of the organization, but not in a consistent and standardized manner. Since the projects are managed according to the preference and knowledge of each individual. Only one company reported that there is a central and documented definition, addressing life cycle and project management control, which is applied to all projects by skilled employees who support the team.

Regarding the benefits of project management, most companies at this level reported that there is some recognition of the benefits that provides project management results in projects developed. Regarding the financial management aspect of companies with low level of maturity seemed very scattered about the answers offered, with two companies reporting that the financial management of the company is best described as project costs not fully accounted and not accompanied by the way they should.

One company reported that financial costs are accounted for by the project manager, in accordance with organizational policies and procedures, another company reported that there is little or no financial control on projects executed, and pointed out that there is a lack of accountability and cost control of projects executed by the company.

The aspects of company human resources and the approach to stakeholder engagement is considered by most companies in just a few projects aimed at stakeholders, being more connected to the project manager than a strategic decision taken by the organization.

One company reported that engagement with those involved in the project is rarely observed and practiced; another company reported that there is a centralized management and a consistent approach to stakeholder engagement and communication used by all projects.

In risk management, it can be observed that most companies have minimal evidence of risk management used for any beneficial action directed to the projects. It can be found documented evidence of risk, but few reports of active management and focused on risk management in projects. Two companies reported that they recognize the risk management in projects executed in the company, but there are inconsistent approaches that result in low levels of effectiveness.

In a survey conducted by Juca Jr., Comforto and Amaral (2010) analyzed the level of maturity in project management of small software development companies, belonging to the technology center of São Carlos. That research involved five companies and analysis of results indicates the early stages of maturity in project management, highlighting the lack of risk management in all of the companies studied.

As for corporate governance, two companies that have addressed some of the corporate governance projects exist informally. Two other companies have indicated that a project management from an organizational perspective is beginning to take shape, with control purpose and without clear strategic control. One company showed that corporate governance is set centrally, and the organizational controls are applied consistently to all projects, with decision-making structures in place and linked to corporate governance.

In the case of resource management, three companies pointed out that resource management is being implemented throughout the organization for the development of projects. However, there is little evidence of a consistent approach in the process of project management companies.

Only one company showed that there is some recognition within the organization need to manage effectively the resources to enable delivery of successful projects, but there is little evidence of resource acquisition, planning or management of these resources.

Finally, three companies considered low maturity index briefly describes the projects that recognize and perform differently from their ongoing activity; hence, the projects in the companies can run informally, without standard process or tracking system. Two companies stated that they make sure that each project is run with its own processes 
and procedures, with a specified minimum standard, making it possible the presence of inconsistencies and limitations of coordination between projects.

\subsubsection{Companies with a high level of maturity}

Analyzing companies with high level of maturity, there are some notable differences with regard to aspects of project management. The general aspects of the organization, most ranked companies with a high level of maturity demonstrate mature behavior through processes that are quantitatively defined and managed, or are controlled by metrics and quantitative techniques. These techniques provide quantitative parameters by which the processes of the projects can be improved continuously.

There is also good evidence that there are quantitative objectives for quality and process performance, and these are used as criteria in the management processes for better results in projects run by companies. Often companies collect project data, and the data collected contribute to the overall structure of the organization's performance measurement, facilitate the analysis of project portfolio, and allow monitoring the current capacity and capacity constraints in project implementation. The top management is proactive and seeks innovative ways to achieve goals.

The use of metrics for project management can effectively control the processes and identify ways to adjust and adapt to particular initiatives, without losing quality. It can be observed in companies with high level of maturity that there is a concern and an effort aimed at aspects of quality and continuous collection of metric data for the purposes of promoting the continuous improvement of processes of projects executed in companies.

Only one company was characterized as focused on the quantitative optimization of its processes to account for the changing needs of business and external factors. The company considers itself capable of anticipating future capacity demands and capability requirements of projects to meet the delivery challenges through portfolio analysis, for example.

The knowledge gained by the organization, about their processes and metrics of the product, allows us to understand the causes of variation and thus improve the performance of projects to be executed in the future. The organization is able to show that the continuous process improvement is enabled by quantitative feedback from their validation processes, incorporating the ideas and innovative technologies. The organization is able to demonstrate strong alignment of organizational goals with business plans, and that reflects through the scope, sponsorship, commitment, planning, resource allocation, risk management and benefits realized.

Regarding the management control aspect, the companies presented themselves scattered about their answers. Since both companies were characterized as having a central definition and documented, addressing life cycle and control in project management, applicable to all projects by skilled employees who support the team of professionals. Two companies reported that the management control ensures that the project approach provides changes in the organization's goals.

Regarding the benefits of project management, two companies indicated that the benefits management approach is grounded in project management, with a focus on performance and results of the project. Since the performance, metrics of the projects tend to be collected and analyzed to promote continuous process improvement projects. Two companies stated that the benefits of management are embedded within the organizational approach to change, configured as part of the development of organizational strategy. Metrics for performance assessment are connected and support the recognition of the benefits of achievement.

In the financial management aspect, three companies responded that there are established standards in financial management for the preparation of case studies and processes for their management throughout the project life cycle.

Project managers control costs and expenses, in accordance with the guidelines and procedures, with defined interfaces with other financial functions within the organization. Only two companies state that the financial control of projects is fully integrated with the organization. In this context, the cost estimation techniques used in the projects are constantly reviewed; real comparisons with the ones estimated are used throughout the organization of projects. In addition, there is evidence of continuous improvement.

Regarding the addressed topic of relationship with stakeholders, all companies with high level of maturity described that there is a centralized management and a consistent approach to stakeholder engagement and communication used by all projects.

As for risk management, three companies stated that the project risk management process is based on a central process, based on the organization's policy for risk management and used consistently. One company noted that risk management works effectively incorporated into all projects, and the value of risk management can be demonstrated by documented evidence. Only one company indicated that there is minimal evidence of risk management used for 
any beneficial effect on the projects. Compared with other companies in the same level of maturity this company was the only one who presented low level in this specific parameter.

Regarding corporate governance, three companies indicated that there is a central definition, where the organizational controls are applied consistently to all projects, with local decision-making structures and linked to corporate governance. Two companies mentioned that there is a clear alignment with the project's decision-making processes, which adopt and integrate with greater organization and that are transparent to stakeholders.

For the management of resources in project management, three companies mentioned that there is a clear alignment of the project with decision-making processes, which adopt and integrate with greater organization, being transparent to stakeholders, and project management responsibilities are embedded in the paper descriptions of the organization consistently. In this aspect of resource management, both companies also mentioned that the organization has defined and approved a set of procedures and management processes for the acquisition, planning and management of project resources.

Finally, the general aspects of project management in organizations that had higher levels of maturity, three companies reported making use of the continuous improvement of processes proactively, noting that management have organized projects to improve their ability to portray the performance over time and optimize processes.

Two companies had to obtain and maintain specific measures on performance management projects, and managing an organization of quality management to better predict future performance, but do not perform continuous process improvement projects extremely efficiently.

\subsection{Analysis among the factors discussed and the importance to companies}

One of the objectives of research is to analyze the relationship of factors involved in project management in companies. In order to develop the research, four interfering factors were identified, related to processes, people, tools, various technologies and tools of quality.

The 'process' factor is classified by the studied companies as the most important project management, but questions of frequency of use of these processes do not correspond to the level of emphasis. The 'people' factor is what got the highest score issues, compared with other factors. As for its relevance, companies assign even greater importance regarding the frequency of usage in enterprises, being the second most prominent topic according to the studied companies.

The quality tools come in third place in the comparison of the relevance factors and use of tools in business, it was also noticed that the level of importance is the higher level of issues. The companies give more importance to the quality tools they actually use in their project management.

The "tools and technologies" factor addresses various issues used in the project management of organizations, this topic is the less prominent in companies, being used less by the companies studied, however, it was perceived that the importance level is higher, since companies give more importance to the various tools and technologies they actually use in project management. Through figure 2 the relationship of the factors discussed and their individual importance can be analyzed.

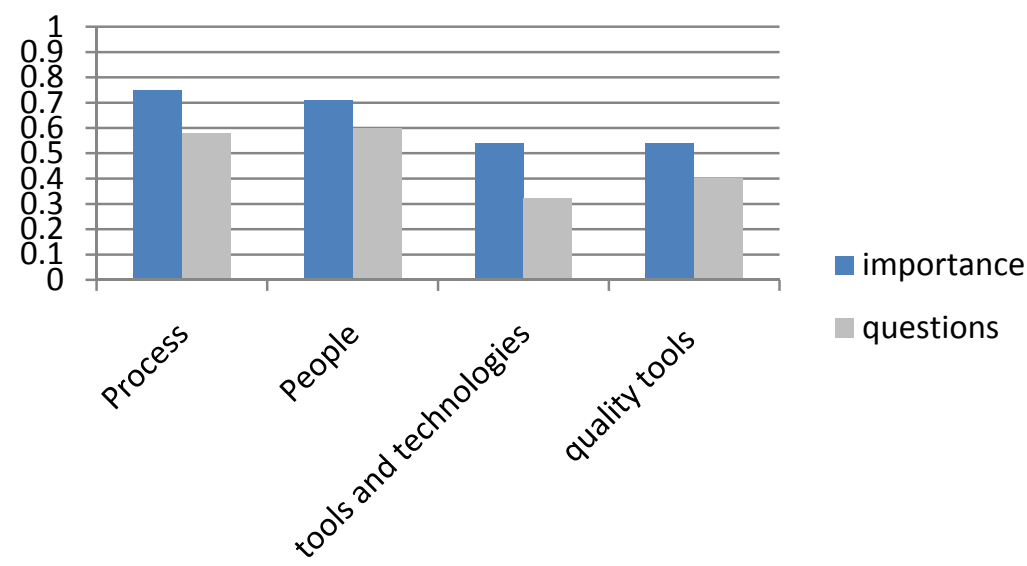

Figure 2. Relationship between the factors discussed and the importance of each factor Source: prepared by authors 


\subsubsection{Aspects of quality management in projects within the studied companies}

A scoring model was adopted in order to classify the topics covered in the project management by the companies. For the accounting data, the average levels of each quality tool studied of all companies participating in the survey was carried out. After the counting of the 29 data questions, they were organized in descending order as presented in Table 4 for the purpose of analyzing each topic on the frequency of use by the companies.

Table 4. Quality tools in project management in decreasing order of priority. Source: prepared by authors

\begin{tabular}{l|l|l|l}
\hline Topic & Question & Topic & Note \\
\hline 1st & Q29 & $\begin{array}{l}\text { Projects eventually are inspected in accordance with the check sheet of the project, to } \\
\text { determine whether they comply with the standards documented. }\end{array}$ & 0.725 \\
\hline 2nd & Q24 & $\begin{array}{l}\text { When appropriate, we used the control chart in the projects to see whether some factor } \\
\text { is out of expected range. }\end{array}$ & 0.493 \\
\hline 3rd & Q26 & $\begin{array}{l}\text { When necessary we used the Pareto chart tool in projects carried out as a graphic } \\
\text { feature used to graphically analyze the frequency of certain occurrences. }\end{array}$ & 0.425 \\
\hline 4th & $\mathbf{Q 2 5}$ & $\begin{array}{l}\text { Frequently we used the histogram tool in projects as a graphical way to present the } \\
\text { frequency distribution of a variable. }\end{array}$ & 0.350 \\
\hline 5th & $\mathbf{Q 2 7}$ & $\begin{array}{l}\text { When necessary we used the execution graph, which shows trends of a process over } \\
\text { time, variation over time or variations or improvements in a process over time. }\end{array}$ & 0.337 \\
\hline 6th & $\mathbf{Q 2 8}$ & $\begin{array}{l}\text { When necessary we used the dispersion chart, this tool allows the quality team to study } \\
\text { and identify the possible relationship between the observed changes in two variables. }\end{array}$ & 0.225 \\
\hline 7th & $\mathbf{Q 1 3}$ & $\begin{array}{l}\text { The cause and effect diagram is used in projects to identify information about the } \\
\text { causes of problems, in order to organize and document the potential causes of an effect } \\
\text { or characteristic of quality. }\end{array}$ & 0.206 \\
\hline 4 & \begin{tabular}{l} 
Comasative \\
\hline
\end{tabular}
\end{tabular}

4.2.2 Comparative analysis of the high and low maturity levels and their quality tools used in the project management within companies

In general, analyzing only the amount of responses provided by companies one can visualize, through Figure 3, that the quantity of responses 'unknown' and 'never', provided by companies with a low maturity level in the projects is higher. Whereas the amount of responses 'seldom', 'sometimes', 'often' and 'always' is higher in companies where the maturity level is high.

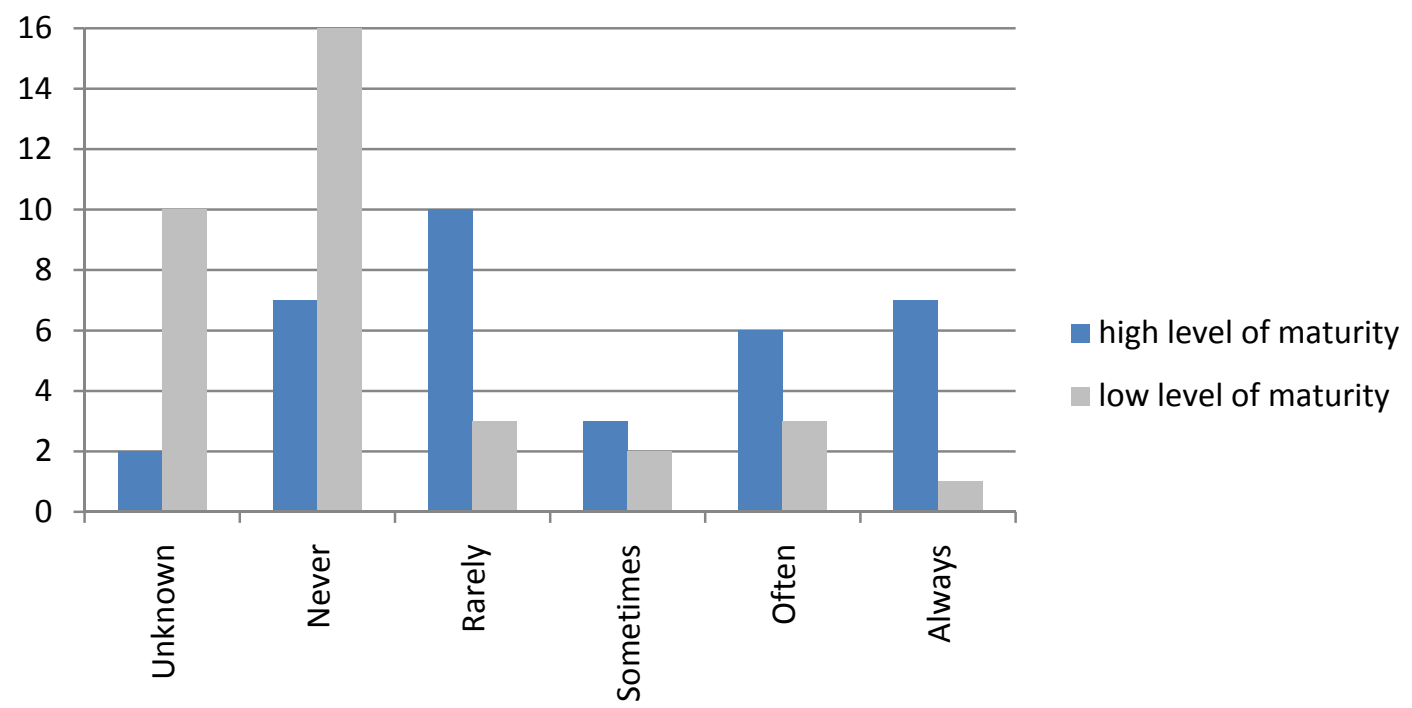

Figure 3. Comparison of the amount of responses from companies with high and low level of maturity.

Source: prepared by authors 
Analyzing the first topic that comes on the check sheet, companies classified in two levels presented it as the most used tool. This tool provides data on the progress and execution of the project that are often used to support other quality tools, or even other tools and technologies of the project. The check sheet is also a very simple and easy tool to implement, as mentioned above, and it can be use in any project and any business, without the need for great expertise.

The control chart appears as the second most important topic at both levels of maturity among the companies investigated. In a comparative analysis, it can be noticed that four companies with a high level of maturity have used this tool with some frequency, whereas in firms with low level of maturity, three companies claimed not knowing the tool or never having used it in their projects.

Noticing the use of Pareto analysis tool, concerning the two groups of companies, we can point out that, among firms with low level of maturity in projects most never use the tool, while for enterprises with high level of maturity, most answered that often use the Pareto analysis tool. Pareto analysis is a tool that requires knowledge for the explanation and interpretation of chart data. It can be seen through Figure 4, the points obtained by comparing two groups of companies on the topic of Pareto analysis.

Regarding the execution graph, most companies with a low level of maturity indicated that they never use the tool; companies with high level of maturity provided answers that are divided between the options rarely, sometimes and often. The execution chart is a tool widely used in the production process; in the project area, few companies have this tool to track their progress.

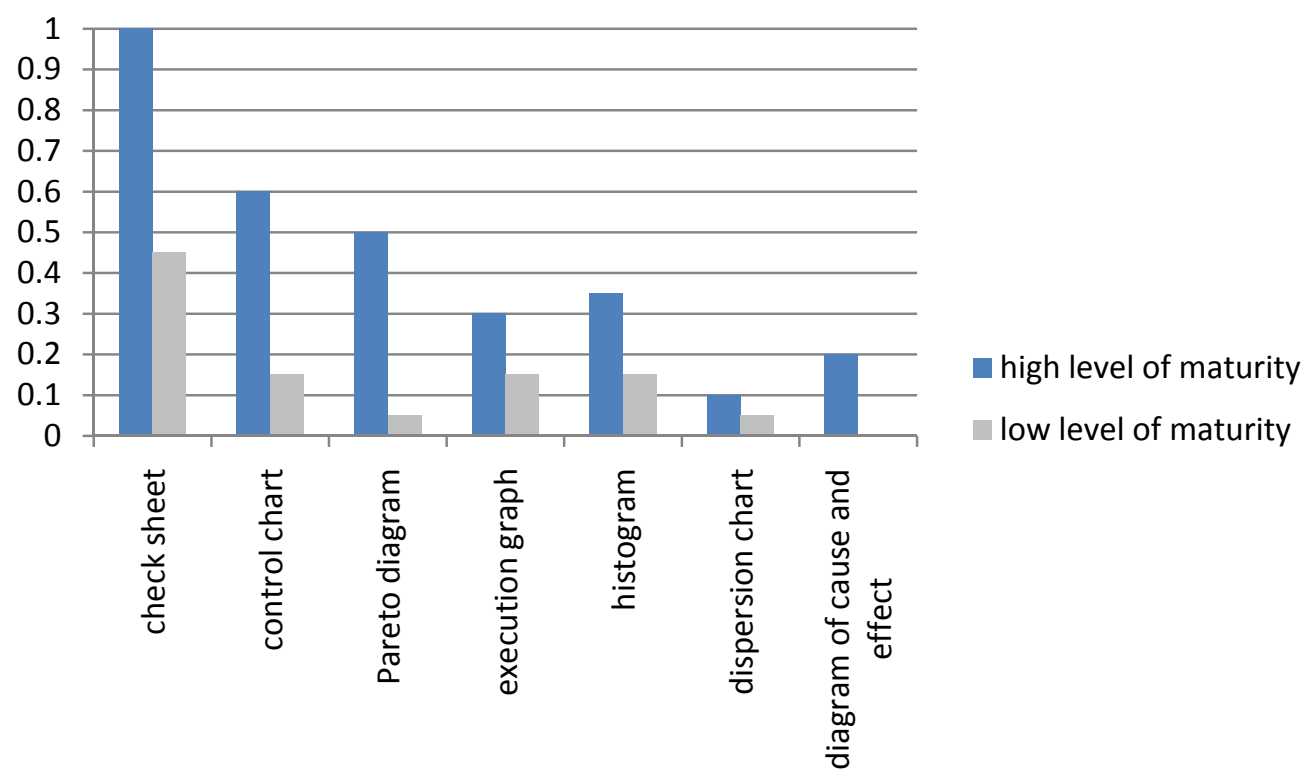

Figure 4. Comparison of notes on quality management in projects among companies in low and high level of maturity in projects. Source: prepared by authors

Proceeding to a comparative analysis between the two groups of companies, a histogram for the tool, it becomes apparent that, relative to firms with low level of maturity, most never use the tool in their executed projects. For businesses with high maturity, the answers are divided between the options never, rarely, sometimes and often. The note in the category histogram is superior when it comes to companies with high maturity, compared with companies with low maturity level in projects.

The dispersion chart is the tool that obtained less difference in comparing the two groups of companies. It is possible to analyze that is the quality tool that is less relevant in the perception and use in projects of companies. Most companies with a low level of maturity showed that ignore or never use the tool in the execution of projects. Whereas in companies with high level of maturity, most companies responded that, they never or rarely use this tool on projects. 
The dispersion chart as well as the execution graph are tools widely used in the production process; hence, many project developers are unaware of the tool application in project management.

For the cause and effect tool, only companies with high level of maturity responded. Although, most companies in this group responded that they rarely use this tool in project execution. Whilst companies with low level of maturity not know or have never used this tool on projects.

In conclusion, a comparative analysis is presented between the level of importance indicated by companies with a high level maturity and low level of maturity. Therefore, the accounting for notes of the topics of importance was conducted. In general, Figure 5 shows that in companies with high maturity the note of importance of tools addressed is higher than companies with a low level of maturity in projects.

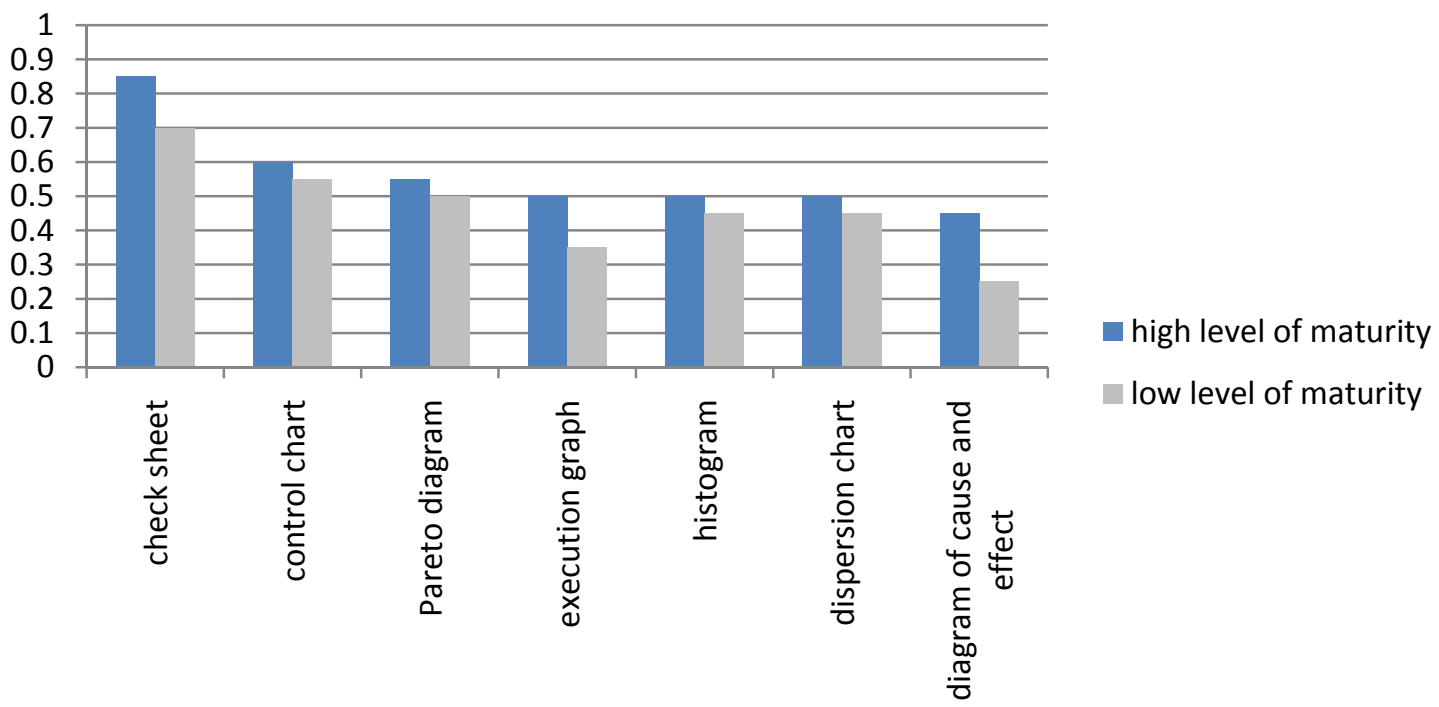

Figure 5. Comparison of notes of importance on quality management in projects between companies in low and high level of maturity in projects

\section{Conclusion and final considerations}

This paper presented the relationship of maturity and quality levels in project management. The survey was conducted in 10 companies, in which were applied two questionnaires (identify the maturity level in the design and quality tools on projects) as the sole source for data analysis. In response to the key question that guided the research, it is possible to observe that companies using quality tools in project management were identified with higher levels of maturity through the model P3M3. After analyzing the results, the study presents some conclusions discussed below

Companies that have knowledge and use quality tools with greater frequency in developing their projects have higher maturity levels. Thus, it is suggested the application and development of quality tools as a factor of maturity in project management companies. The quality tools most used by companies in the survey were check sheet, control chart, Pareto diagram, histogram, execution graph, dispersion chart and diagram of cause and effect.

The comparative analysis of the four factors mentioned above, the factor quality tools comes in third place in the comparison of the factors of relevance and use of tools in the business. The companies give more importance to the quality tools they actually use in their project management. It is noteworthy that the methodology of data analysis, prioritizing the most relevant topics, depending on the responses of firms with scores assigned was efficient for the development of this research.

The survey indicates the existence of a direct association between higher levels of project management and knowledge and frequency of use of quality tools. In the analysis of the relationship between importance and frequency of use of quality tools in the projects it can be concluded that companies consider the quality tools more important compared with the frequency of their use in projects.

In addition, it is concluded that it points out the methodology for the identification of project maturity P3M3, adopted in the survey, was efficient for the development of this study. 


\section{References}

Andersen, E.S; Jessen, S.A. (2003). Project maturity in organizations. International Journal of Project Management, August 2003, Vol.21(6), pp.457-461. http://dx.doi.org/10.1016/S0263-7863(02)00088-1

Aubry, M; Müller, R; Hobbs, B; Blomquist, T. (2010). Project management offices in transition. International Journal of Project Management, December $\quad 2010, \quad$ Vol.28(8), pp.766-778. http://dx.doi.org/</b >10.1016/j.ijproman.2010.05.006

BOlleS, L. D; HUBBARD, G. D. (2006). The Power of Enterprise-Wide Project Management. New York: Amazom Books, 2006. 304p.

Caulliraux, H.M; Spiengel, T.; Proença, A. (2012). Process Management and Organizational Structure in Large Brazilian Companies: Multiple Case Study. Business and Management Research, December 2010, Vol.1(2), . http://dx.doi.org/10.5430/bmr.v1n2p48

Ellis, K.; Berry, D.M. (2013). Quantifying the impact of requirements definition and management process maturity on project outcome in large business application development. Requirements Engineering, September 2013, Vol.18(3), pp.223-249. http://dx.doi.org/10.1007/s00766-012-0146-3

Flybjerg, B; Jessen, S.A. (2013). Quality control and due diligence in project management: getting decisions right by taking the outside view. International Journal of Project Management, July 2003, Vol.31(5), pp.760-774. http://dx.doi.org/10.1016/j.ijproman.2012.10.007

Garel, G. (2013). A history of project management models: From pre-models to the standard models. International Journal of Project Management, July, 2013, Vol.31 (5), p.663-669. http://dx.doi.org/10.1016/j.ijproman.2012.12.011

Juca JR, A.S; Conforto, E.C.; Amaral, D.C. (2010). Maturity in project management in small software development companies from High Technology Polo of São Carlos. Gestão e Produção. Vol.17 (1). (in Portuguese)

KERZNER, H. Project management: a systems approach to planning, scheduling, and controlling. New Jersey: John Wiley \& Sons, 2009. 1094p.

Kumar, A.K; Mangalam, C.K. (2012). Release process on quality improvement in open source software project management. Journal of Computer Science, August 2012, Vol.8(6), pp.1008-1011. http://dx.doi.org/10.3844/jcssp.2012.1008.1011

Moraes, R.O; Barbin Laurindo, F.J. (2013). Maturity and Performance in Information Technology Project Management. Journal of Technology Management \& Innovation, Feb. 2013, Vol.8 (1), pp.3-13. http://dx.doi.org/10.4067/S0718-27242013000300003

P.W.G. Morris, J.K. Pinto, J. Söderlund (Eds.), The Oxford Handbook of Project Management, Oxford university press, New York (2011), pp. 37-64. http://dx.doi.org/10.1093/oxfordhb/9780199563142.001.0001

Passian, B.; Sankaran, S.; Boyodell, S. (2012). Project management maturity: a critical analysis of existing and emergent factors. International Journal of Managing Projects in Business, 2012, Vol.5(1), pp.146-157. http://dx.doi.org/10.1108/17538371211192946

PMBOK. (2013). Project Management Institute, Philadelphia, USA. A Guide to Project Management Knowledge (PMBOK Guide) - Fifth Edition. Philadelphia, 2009, 386 p.

Ojiako, U.; Ashleigh, M.; Chipulu, M.; Maguire, S. (2011). Learning and teaching challenges in project management. International Journal of Project Management, April 2011, Vol 29(3), pp.268-278. http://dx.doi.org/10.1016/j.ijproman.2010.03.008

Yingsheng D.; Youchun T. (2013). A Literature Review on the Relationship Between Service Quality and Customer Loyalty. Business and Management Research, 2013, Vol.3(3). http://dx.doi.org/10.5430/bmr.v3n3p27

Zhang, P.; London, K. (2013). Towards an internationalized sustainable industrial competitiveness model. Competitiveness Review: An International Business Journal, 2013, Vol. 23(2), p.95-113. http://dx.doi.org/10.1108/10595421311305325 
Appendix: Questionnaire used in the survey

\begin{tabular}{|c|c|c|c|c|c|c|c|c|}
\hline $\mathbf{Q}$ & Topics & Unknown & Never & Rarely & Sometimes & Often & Always & $\begin{array}{c}\text { Level of } \\
\text { importance }\end{array}$ \\
\hline 1 & $\begin{array}{l}\text { The actions to be } \\
\text { performed in the project } \\
\text { are described and } \\
\text { specified, offering to } \\
\text { project's members } \\
\text { clarity on the actions to } \\
\text { be performed. }\end{array}$ & $\square$ & $\square$ & $\square$ & $\square$ & $\square$ & $\square$ & $\begin{array}{l}\square 0 \\
\square 3 \\
\square 5 \\
\square 7 \\
\square 10\end{array}$ \\
\hline 2 & $\begin{array}{l}\text { The project execution } \\
\text { has well-established } \\
\text { techniques of research, } \\
\text { providing guidelines for } \\
\text { steps to be performed. }\end{array}$ & $\square$ & $\square$ & $\square$ & $\square$ & $\square$ & $\square$ & $\begin{array}{l}\square 0 \\
\square 3 \\
\square 5 \\
\square 7 \\
\square 10\end{array}$ \\
\hline 3 & $\begin{array}{l}\text { A project statement is } \\
\text { defined and understood } \\
\text { by all involved in the } \\
\text { project, containing a } \\
\text { description of the } \\
\text { project, the major } \\
\text { project deliverables and } \\
\text { acceptance criteria. }\end{array}$ & $\square$ & $\square$ & $\square$ & $\square$ & $\square$ & $\square$ & $\begin{array}{r}\square 0 \\
\square 3 \\
\square 5 \\
\square 7 \\
\square 10\end{array}$ \\
\hline 4 & $\begin{array}{l}\text { It is used the WBS to } \\
\text { identify project } \\
\text { deliverables, works and } \\
\text { control accounts used to } \\
\text { measure project } \\
\text { performance. }\end{array}$ & $\square$ & $\square$ & $\square$ & $\square$ & $\square$ & $\square$ & $\begin{array}{l}\square 0 \\
\square 3 \\
\square 5 \\
\square 7 \\
\square 10\end{array}$ \\
\hline 5 & $\begin{array}{l}\text { The baseline project } \\
\text { schedule is established } \\
\text { and is known by all } \\
\text { people involved in the } \\
\text { project, the baseline } \\
\text { schedule contains begin } \\
\text { and end and deadlines to } \\
\text { goals }\end{array}$ & $\square$ & $\square$ & $\square$ & $\square$ & $\square$ & $\square$ & $\begin{array}{r}\square 0 \\
\square 3 \\
\square 5 \\
\square 7 \\
\square 10\end{array}$ \\
\hline 6 & $\begin{array}{l}\text { Project risks are } \\
\text { identified and recorded, } \\
\text { containing information } \\
\text { about the threats and } \\
\text { opportunities that may } \\
\text { affect the project quality } \\
\text { requirements. }\end{array}$ & $\square$ & $\square$ & $\square$ & $\square$ & $\square$ & $\square$ & $\begin{array}{l}\square 0 \\
\square 3 \\
\square 5 \\
\square 7 \\
\square 10\end{array}$ \\
\hline
\end{tabular}




\begin{tabular}{|c|c|c|c|c|c|c|c|c|}
\hline $\mathbf{Q}$ & Topics & Unknown & Never & Rarely & Sometimes & Often & Always & $\begin{array}{c}\text { Level of } \\
\text { importance }\end{array}$ \\
\hline 7 & $\begin{array}{l}\text { The project budget is } \\
\text { established, and is } \\
\text { known by everyone } \\
\text { involved in the project }\end{array}$ & $\square$ & $\square$ & $\square$ & $\square$ & $\square$ & 口 & $\begin{array}{l}\square 0 \\
\square 3 \\
\square 5 \\
\square 7 \\
\square 10\end{array}$ \\
\hline 8 & $\begin{array}{c}\text { It is the knowledge of } \\
\text { all members company } \\
\text { the standards regarding } \\
\text { development projects, as } \\
\text { well as working } \\
\text { conditions and company } \\
\text { guidelines. }\end{array}$ & $\square$ & $\square$ & $\square$ & 口 & $\square$ & $\square$ & $\begin{array}{l}\square 0 \\
\square 3 \\
\square 5 \\
\square 7 \\
\square 10\end{array}$ \\
\hline 9 & $\begin{array}{l}\text { Stakeholders are aware } \\
\text { of the importance of } \\
\text { each one, as well their } \\
\text { skills and importance to } \\
\text { the Project }\end{array}$ & $\square$ & $\square$ & $\square$ & $\square$ & $\square$ & $\square$ & $\begin{array}{l}\square 0 \\
\square 3 \\
\square 5 \\
\square 7 \\
\square 10\end{array}$ \\
\hline 10 & $\begin{array}{l}\text { The brainstorming } \\
\text { technique is used to } \\
\text { identify potential } \\
\text { problems, risks and } \\
\text { offer alternatives to the } \\
\text { problems in projects. }\end{array}$ & $\square$ & $\square$ & 口 & 口 & 口 & $\square$ & $\begin{array}{l}\square 0 \\
\square 3 \\
\square 5 \\
\square 7 \\
\square 10\end{array}$ \\
\hline 11 & $\begin{array}{l}\text { The affinity diagram is } \\
\text { used to organize the } \\
\text { collected data and group } \\
\text { them into several groups } \\
\text { obeying their relations } \\
\text { and affinities in many } \\
\text { segments of projects. }\end{array}$ & $\square$ & $\square$ & $\square$ & $\square$ & $\square$ & $\square$ & $\begin{array}{l}\square 0 \\
\square 3 \\
\square 5 \\
\square 7 \\
\square 10\end{array}$ \\
\hline 12 & $\begin{array}{l}\text { It is identified in } \\
\text { projects forces and } \\
\text { restrictions, seeking to } \\
\text { maximize the forces and } \\
\text { reduce restrictions. }\end{array}$ & $\square$ & $\square$ & $\square$ & $\square$ & $\square$ & $\square$ & $\begin{array}{l}\square 0 \\
\square 3 \\
\square 5 \\
\square 7 \\
\square 10\end{array}$ \\
\hline
\end{tabular}




\begin{tabular}{|c|c|c|c|c|c|c|c|c|}
\hline $\mathbf{Q}$ & Topics & Unknown & Never & Rarely & Sometimes & Often & Always & $\begin{array}{c}\text { Level of } \\
\text { importance }\end{array}$ \\
\hline 13 & $\begin{array}{l}\text { The cause and effect } \\
\text { diagram is used in } \\
\text { projects to identify } \\
\text { information about the } \\
\text { causes of problems, in } \\
\text { order to organize and } \\
\text { document the potential } \\
\text { causes of an effect or } \\
\text { characteristic of quality. }\end{array}$ & $\square$ & $\square$ & $\square$ & $\square$ & $\square$ & $\square$ & $\begin{array}{r}\square 0 \\
\square 3 \\
\square 5 \\
\square 7 \\
\square 10\end{array}$ \\
\hline 14 & $\begin{array}{l}\text { In developed projects } \\
\text { we use the tree diagram } \\
\text { to unfold an idea, a } \\
\text { concept, a task or } \\
\text { processes in basic } \\
\text { components, allowing it } \\
\text { to be better known. }\end{array}$ & $\square$ & $\square$ & $\square$ & $\square$ & $\square$ & $\square$ & $\begin{array}{l}\square 0 \\
\square 3 \\
\square 5 \\
\square 7 \\
\square 10\end{array}$ \\
\hline 15 & $\begin{array}{c}\text { We use the tool } \\
\text { prioritization matrix as a } \\
\text { way to classify a set of } \\
\text { problems. }\end{array}$ & $\square$ & $\square$ & $\square$ & $\square$ & $\square$ & $\square$ & $\begin{array}{l}\square 0 \\
\square 3 \\
\square 5 \\
\square 7 \\
\square 10\end{array}$ \\
\hline 16 & $\begin{array}{l}\text { In process view, we use } \\
\text { flow charts to show the } \\
\text { activities, decision } \\
\text { points and the order } \\
\text { processing. Through the } \\
\text { flowchart can predict } \\
\text { the quality problems in } \\
\text { design. }\end{array}$ & $\square$ & $\square$ & $\square$ & $\square$ & $\square$ & $\square$ & $\begin{array}{l}\square 0 \\
\square 3 \\
\square 5 \\
\square 7 \\
\square 10\end{array}$ \\
\hline 17 & $\begin{array}{l}\text { To view the macro } \\
\text { shape of the project } \\
\text { process, we use the } \\
\text { SIPOC tool. }\end{array}$ & $\square$ & $\square$ & $\square$ & $\square$ & $\square$ & $\square$ & $\begin{array}{l}\square 0 \\
\square 3 \\
\square 5 \\
\square 7 \\
\square 10\end{array}$ \\
\hline 18 & $\begin{array}{l}\text { It uses the FMEA tool to } \\
\text { prevent failures in } \\
\text { projects of product or } \\
\text { processes. The FMEA } \\
\text { allows the analysis of } \\
\text { potential failures and } \\
\text { proposals for } \\
\text { improvement actions. }\end{array}$ & $\square$ & $\square$ & $\square$ & $\square$ & $\square$ & $\square$ & $\begin{array}{l}\square 0 \\
\square 3 \\
\square 5 \\
\square 7 \\
\square 10\end{array}$ \\
\hline
\end{tabular}




\begin{tabular}{|c|c|c|c|c|c|c|c|c|}
\hline $\mathbf{Q}$ & Topics & Unknown & Never & Rarely & Sometimes & Often & Always & $\begin{array}{c}\text { Level of } \\
\text { importance }\end{array}$ \\
\hline 19 & $\begin{array}{l}\text { Time analysis of the } \\
\text { processes executed in } \\
\text { the project is made. }\end{array}$ & $\square$ & 口 & 口 & 口 & $\square$ & $\square$ & $\begin{array}{l}\square 0 \\
\square 3 \\
\square 5 \\
\square 7 \\
\square 10\end{array}$ \\
\hline 20 & $\begin{array}{l}\text { Actions that do not add } \\
\text { value to the project are } \\
\text { identified. }\end{array}$ & 口 & 口 & $\square$ & 口 & 口 & $\square$ & $\begin{array}{l}\square 0 \\
\square 3 \\
\square 5 \\
\square 7 \\
\square 10\end{array}$ \\
\hline 21 & $\begin{array}{l}\text { The project action plan } \\
\text { is done through the } \\
5 \mathrm{~W} 2 \mathrm{H} \text { tool. This tool } \\
\text { establishes a form to } \\
\text { execution and control of } \\
\text { tasks, the } \\
\text { responsibilities and how } \\
\text { the work should be } \\
\text { performed. }\end{array}$ & $\square$ & $\square$ & $\square$ & $\square$ & $\square$ & $\square$ & $\begin{array}{l}\square 0 \\
\square 3 \\
\square 5 \\
\square 7 \\
\square 10\end{array}$ \\
\hline 22 & $\begin{array}{l}\text { The array of } \\
\text { responsibility is } \\
\text { presented to all people } \\
\text { involved projects, helps } \\
\text { everyone understand } \\
\text { expectations and their } \\
\text { responsibilities. }\end{array}$ & 口 & 口 & 口 & 口 & $\square$ & $\square$ & $\begin{array}{l}\square 0 \\
\square 3 \\
\square 5 \\
\square 7 \\
\square 10\end{array}$ \\
\hline 23 & $\begin{array}{l}\text { The project tasks are } \\
\text { modeled and planned by } \\
\text { Gantt tool that aids in } \\
\text { the visualization of the } \\
\text { project progress as well } \\
\text { as communication } \\
\text { between project } \\
\text { stakeholders. }\end{array}$ & $\square$ & $\square$ & $\square$ & 口 & 口 & $\square$ & $\begin{array}{l}\square 0 \\
\square 3 \\
\square 5 \\
\square 7 \\
\square 10\end{array}$ \\
\hline 24 & $\begin{array}{l}\text { When appropriate, we } \\
\text { used the control chart in } \\
\text { the projects to see } \\
\text { whether some factor is } \\
\text { out of expected range. }\end{array}$ & $\square$ & $\square$ & 口 & 口 & $\square$ & $\square$ & $\begin{array}{l}\square 0 \\
\square 3 \\
\square 5 \\
\square 7 \\
\square 10\end{array}$ \\
\hline
\end{tabular}




\begin{tabular}{|c|c|c|c|c|c|c|c|c|}
\hline $\mathbf{Q}$ & Topics & Unknown & Never & Rarely & Sometimes & Often & Always & $\begin{array}{c}\text { Level of } \\
\text { importance }\end{array}$ \\
\hline 25 & $\begin{array}{l}\text { Frequently we used the } \\
\text { histogram tool in } \\
\text { projects as a graphical } \\
\text { way to present the } \\
\text { frequency distribution } \\
\text { of a variable. }\end{array}$ & $\square$ & $\square$ & 口 & $\square$ & $\square$ & 口 & $\begin{array}{l}\square 0 \\
\square 3 \\
\square 5 \\
\square 7 \\
\square 10\end{array}$ \\
\hline 26 & $\begin{array}{l}\text { When necessary we } \\
\text { used the Pareto chart } \\
\text { tool in projects carried } \\
\text { out as a graphic feature } \\
\text { used to graphically } \\
\text { analyze the frequency of } \\
\text { certain occurrences. }\end{array}$ & $\square$ & $\square$ & $\square$ & $\square$ & $\square$ & $\square$ & $\begin{array}{l}\square 0 \\
\square 3 \\
\square 5 \\
\square 7 \\
\square 10\end{array}$ \\
\hline 27 & $\begin{array}{l}\text { When necessary we } \\
\text { used the execution } \\
\text { graph, which shows } \\
\text { trends of a process over } \\
\text { time, variation over time } \\
\text { or variations or } \\
\text { improvements in a } \\
\text { process over time. }\end{array}$ & $\square$ & $\square$ & $\square$ & $\square$ & $\square$ & $\square$ & $\begin{array}{l}\square 0 \\
\square 3 \\
\square 5 \\
\square 7 \\
\square 10\end{array}$ \\
\hline 28 & $\begin{array}{l}\text { When necessary we } \\
\text { used the dispersion } \\
\text { chart, this tool allows } \\
\text { the quality team to study } \\
\text { and identify the possible } \\
\text { relationship between the } \\
\text { observed changes in two } \\
\text { variables. }\end{array}$ & $\square$ & $\square$ & $\square$ & $\square$ & $\square$ & $\square$ & $\begin{array}{l}\square 0 \\
\square 3 \\
\square 5 \\
\square 7 \\
\square 10\end{array}$ \\
\hline 29 & $\begin{array}{c}\text { Projects eventually are } \\
\text { inspected in accordance } \\
\text { with the check sheet of } \\
\text { the project, to determine } \\
\text { whether they comply } \\
\text { with the standards } \\
\text { documented. }\end{array}$ & $\square$ & $\square$ & $\square$ & $\square$ & $\square$ & $\square$ & $\begin{array}{l}\square 0 \\
\square 3 \\
\square 5 \\
\square 7 \\
\square 10\end{array}$ \\
\hline
\end{tabular}

